\author{
Wioletta Nogaj \\ Uniwersytet Ekonomiczny \\ w Krakowie
}

\title{
Globalizacja a lokalizacja działalności gospodarczej
}

Jednym z głównych zjawisk zachodzących we współczesnym świecie jest zjawisko globalizacji. Dotyka ono wszystkich bez wyjątku państw oraz gospodarek. Z procesem globalizacji wiążą się szybkie przepływy towarów, usług i kapitału, migracje ludzi oraz gwałtowna ekspansja korporacji transnarodowych. To one wprowadzają zasady planowania strategicznego i optymalizację produkcji w globalnej skali, a także przesuwają produkcję przemysłową do krajów i regionów świata o niższych kosztach wytwarzania. Procesy nowej fazy globalizacji kojarzą się nieodłącznie ze zmianą lokalizacji miejsc pracy, produkcji i świadczenia usług. Działania te odzwierciedlają zmiany w funkcjonowaniu przedsiębiorstw i wynikają z adaptacji firm do coraz bardziej konkurencyjnego środowiska, w którym działają oraz z szybkich zmian technologicznych (Hetmańczyk, Noga 2008).

Prawdopodobnie po raz pierwszy termin globalizacja pojawił się w roku $1959 \mathrm{w}$ tygodniku „The Economist” (Sala 2006). W literaturze brak jest powszechnie akceptowanej definicji tego pojęcia. Przykładowo A. Stabryła rozpatruje zjawisko globalizacji zarówno w wąskim, jak i w szerokim zakresie. W wąskim ujęciu globalizacja odnosi się do przedsięwzięć rynkowych, które są charakteryzowane przez produkt globalny (uniwersalny nie zaś lokalny) oraz przez podobne gusty klientów na całym świecie. Natomiast w ujęciu szerokim globalizacja dotyczy stanu myślenia i działania firm opartego na światowej perspektywie, integrującego w jeden system klientów, zasoby, technologię wytwarzania, koszty, układy kooperacyjne i alianse oraz konkurentów (Stabryła 2007). Wielu autorów podejmujących próbę stworzenia definicji globalizacji odwołuje się do pojęcia procesu, definiując globalizację jako:

- proces pogłębiania się światowych powiązań we wszystkich aspektach współczesnego życia politycznego, społecznego, ekonomicznego i kulturowego (Liberska 2002),

- ogólnoświatowe (kontynentalne, regionalne) procesy obejmujące postęp techniczno-organizacyjny, technologie komunikacyjne, nowe formy współpracy politycznej i ekonomicznej między państwami, które determinują procesy gospodarowania i zarządzania organizacjami (Potocki 2009),

- proces stopniowego, realnego scalania gospodarek narodowych, przejawiający się w dynamicznym wzroście obrotów handlowych, międzynarodowych przepływów kapitałowych i usługowych oraz rosnącej tendencji do traktowania całego świata jako rynku zbytu przez coraz większą liczbę przedsiębiorstw (Budnikowski 2000),

- historyczny i spontaniczny proces liberalizacji i postępującej wraz z nią integracji funkcjonujących dotychczas w odosobnieniu lub luźno powiązanych rynków towarów, kapitału i z opóźnieniem i na mniejszą skalę rynku siły roboczej oraz technologii i informacji w jeden współzależny rynek światowy (Kołodko 2008), 
- proces bliższej ekonomicznej integracji rynków globalnych: finansowego, produktu i pracy (Gurría 2006),

- proces, który jest tworzony przez zjawiska lub działania o wymiarze ogólnoświatowym (Zaorska 1998),

- proces rosnącej wielopłaszczyznowej (tj. ekonomicznej, społecznej, kulturowej, politycznej) współzależności pomiędzy poszczególnymi krajami i regionami, wskutek czego dochodzi do powstania silnie zintegrowanego rynku światowego (Matysek-Jędrych 2008).

Powyższe definicje potwierdzają słuszność opinii B. De Wita oraz R. Meyera o tym, że termin globalizacja odnosi się do trzech elementów, którymi są:

- ogólnoświatowy zasięg - znaczenie geograficzne, oznacza przedsiębiorstwo obejmujące swoją działalnością cały świat, w odróżnieniu od przedsiębiorstw o zasięgu lokalnym (krajowym) lub regionalnym (kilka krajów),

- ogólnoświatowa jednorodność - zanikanie międzynarodowej różnorodności oznacza przedsiębiorstwo sprzedające ten sam produkt na wszystkich obsługiwanych rynkach geograficznych, w odróżnieniu od produktu dopasowanego do lokalnej specyfiki,

- ogólnoświatowa integracja - kategoria zależności i zacieśniania powiązań międzynarodowych, oznacza przedsiębiorstwo, które wyraźnie odczuwa skutki zdarzeń zachodzących w innych krajach, w odróżnieniu od rynku lokalnego, gdzie sytuacja zagraniczna ma znikomy wpływ na poziom cen, dynamikę konkurencji, popyt i obowiązujące mody (Wit, Meyer 2007).

W naukach o zarządzaniu czasami utożsamiane są ze sobą dwa różne wymiary globalizacji: globalizacja rynków i globalizacja sektorów. Jest to błędne postępowanie, ponieważ każdy z tych wymiarów niesie odmienne następstwa dla różnych aspektów strategii funkcjonowania organizacji. Globalizacja sektorów jawi się jako druga strona globalizacji rynków. Jeżeli globalna działalność przedsiębiorstwa na rynku koncentruje się na rozpoznawaniu i zaspokajaniu potrzeb konsumentów, to działalność globalna w sektorze skupia się na organizowaniu i koordynowaniu funkcji produkcyjnych poza granicami państwa. Te dwa wymiary globalizacji mają określony wpływ na zarządzanie przedsiębiorstwami w warunkach globalizacji, która w tym kontekście staje się szansą, ale także niesie za sobą zagrożenia (Potocki 2004).

Dociekliwi badacze historii gospodarczej odnajdują korzenie globalizacji w odległych wiekach, w których nastąpił rozwój długodystansowego transportu i rozszerzyły się możliwości komunikowania między ludźmi. W literaturze można spotkać opinie o pionierskiej roli ekspansji buddyzmu i chrześcijaństwa na początku naszej ery, islamu w VII-IX w., pochodu Czyngis-Chana w XIII w. czy rozwoju Imperium Ottomańskiego w XIV w. Jednak szczególne znaczenie przypisuje się wielkim odkryciom geograficznym w XV i XVI w., współcześnie określanym mianem spotkania cywilizacji. Odkrycia geograficzne i wywołany przez nie rozwój handlu ukształtowały kapitalizm merkantylny. Gospodarkę rynkową promowała następnie ideologia liberalizmu, która wyrosła w epoce Oświecenia (Kaliński 2004). Przedstawiciele merkantylizmu udowodnili, że podstawą istnienia bogatych państw jest kapitalistyczne uprzemysłowienie oraz przyspieszony rozwój, realizowany poprzez handel zamorski oraz rodzimą produkcję chronioną przez system monarchii absolutnej. Doprowadziło to m.in. do odkrycia, a następnie eksploatacji kontynentu amerykańskiego oraz dało początek bardzo szybkiemu rozwojowi wymiany międzynarodowej, tworząc na świecie centra gospodarcze mające wpływ na sposób produkowania oraz na procesy dystrybucyjne w wielu różnych gospodarkach narodowych. Na skutek tych zjawisk doszło do międzynarodowego podziału pracy i podporządkowania się większości krajów najwyżej rozwiniętym gospodarkom rynkowym. 
Pojęcie globalizacji nie odnosi się tylko do działalności przemysłowej, ale również do rynków finansowych i pieniężnych (Bednarek 2007). Patrząc przez pryzmat czasu i kosztów transportu, nasza planeta skurczyła się obecnie do rozmiarów globalnej wioski. Wielu ludzi przyjmuje za fakt oczywisty możliwość dostępu do produktów z całego świata oraz możliwość odbywania szybkich i bezpiecznych podróży międzykontynentalnych (Harrison, Hoek 2010). Z punktu widzenia nauki i praktyki zarządzania można przyjąć, że początki zainteresowania terminem globalizacja wynikały z procesów koncentracji kapitału i powstania wielkich ponadnarodowych koncernów, co miało miejsce w drugiej połowie XX w. (Potocki 2004)

Obecna faza globalizacji różni się od poprzednich przede wszystkim tym, że nowoczesne technologie informacyjne i komunikacyjne doprowadziły do gwałtownego wzrostu handlu usługami oraz do zastąpienia fordowskiej produkcji masowej elastycznymi systemami produkcji. Dzisiejsza faza globalizacji charakteryzuje się specyficznym zestawem cech o charakterze zarówno ekonomicznym, jak i pozaekonomicznym. Do tych pierwszych zaliczamy m.in. wzrost obrotów handlowych, inwestycji oraz przepływów finansowych i technologicznych. Po stronie tych drugich można wymienić m.in. rosnącą uniformizację społecznych systemów wartości, będącą rezultatem standaryzacji gustów konsumpcyjnych oraz częściowej utraty suwerenności narodowej. Ekonomiści są zgodni co do tego, że w przyspieszeniu procesu globalizacji ogromną rolę odegrał handel światowy, który w latach 1820-1992 wzrósł 540 razy, podczas gdy liczba ludności na świecie zwiększyła się tylko pięciokrotnie. Do ważnych nowych zjawisk, które zaistniały po drugiej wojnie światowej, należy zaliczyć szybszy wzrost handlu usługami niż handlu wyrobami przemysłowymi, a także dość istotną zmianę struktury eksportu krajów rozwijających się, polegającą na zwiększonym udziale sprzedaży wyrobów przetworzonych kosztem wyrobów surowcowych (Piasecki 2003).

Globalizacja niesie ze sobą bezprecedensowe możliwości uzyskania korzyści ekonomicznych, ale dostęp do tych możliwości nie jest równie łatwy dla wszystkich; wręcz przeciwnie: dla jednych jest bardzo łatwy, dla innych - zamknięty. Im łatwiejszy jest dostęp do Internetu, do globalnych zasobów wiedzy, do globalnej infrastruktury finansowej i innych sieci, tym większe zyski można osiągnąć z działalności gospodarczej, szczególnie w skali globalnej oraz tym łatwiej jest taką działalność rozpocząć lub kontynuować (Flejtarski, Wahl 2003).

Efektem globalizacji jest nie tylko zmniejszenie dystansu między państwami a regionami, zwiększenie się rynków istniejących faktycznie i wirtualnie, ale też pogłębienie różnic między krajami rozwiniętymi a rozwijającymi się, regionami i miastami bogatymi a ubogimi, powodujące rewolucyjne zmiany o charakterze pozytywnym lub negatywnym (Bednarek 2007).

Entuzjaści globalizacji podkreślają jej następujące zalety:

- wzrost efektywności i konkurencyjności,

- spadek kosztów produkcji i komunikacji,

- liberalizacja i demokratyzacja systemu światowego,

- możliwość przyspieszenia wzrostu w obszarach zacofanych,

- zwiększona możliwość uczestnictwa w procesach światowych,

- wyłanianie się nowych (wschodzących) rynków i podmiotów gospodarczych,

- wzrost jakości wyrobów i usług,

- powstawanie nowych zawodów,

- stopniowe zanikanie barier we współpracy międzynarodowej,

- wzrost świadomości międzynarodowej i myślenia globalnego,

- większa współpraca międzynarodowa przy rozwiązywaniu wspólnych problemów,

- wzrost pluralizmu na światowej scenie politycznej,

- łatwiejszy dostęp do zróżnicowanych dóbr i usług, nowych technologii, metod zarządzania, instytucji, osiągnięć kulturowych, rozrywki,

- przyspieszona dyfuzja postępu naukowo-technicznego, 
- upodobnianie się wzorców rozwoju społeczno-ekonomicznego,

- normalizacja i standaryzacja w skali świata,

- możliwość transferu kapitału do słabiej rozwiniętych gospodarek (Flejterski, Wahl 2003).

Z kolei W. Misiak wskazuje na następujące ekonomiczno-społeczne procesy i zjawiska towarzyszące globalizacji, które są postrzegane jako jej wady:

- nierówności w rozwoju ekonomicznym,

- rozpiętości w dochodach i poziomie życia - „bogaci się bogacą, biedni biednieją”,

- działalność Banku Światowego, Międzynarodowego Funduszu Walutowego, Światowej Organizacji Handlu, Unii Europejskiej i innych organizacji ponadnarodowych,

- eksploatacja środowiska naturalnego bez troski o przyszłe pokolenia,

- „demokracja selektywna” (typ demokracji, w której ważne jest „,co pasuje władzy”), winna być zastąpiona „demokracją partycypacyjną”,

- zagrożenie suwerenności politycznej, państwowej i narodowej,

- polityczna i ekonomiczna zależność mediów,

- degradacja i zagrożenie kultur narodowych, regionalnych i lokalnych,

- unifikacja kultury w skali globalnej,

- wyzysk pracowników w wielkich korporacjach,

- dyskryminacja kobiet,

- zatrudnianie dzieci,

- kontestacje w stosunku do swoiście interpretowanego przez władze pojęcia interesy społeczne, na szczeblu centralnym i lokalnym (W. Misiak 2007).

Globalizacja jest zatem procesem, który niesie za sobą wiele wyzwań i zagrożeń, ale jak zauważył J.P. Jeannet w Managing with a Global Mindset, globalizacja nie jest ani modą, ani tymczasowym trendem, globalizacja jest faktem, do którego większość firm i menedżerów będzie musiała się przystosować (Jeannet 2000).

\section{Lokalizacja działalności gospodarczej}

Z punktu widzenia zarządzania przedsiębiorstwem najistotniejszą kwestią związaną z globalizacją jest dostrzeganie tego, co determinuje działania firmy z perspektywy światowej. Oznacza to przede wszystkim dobór metod i filozofii zarządzania, które pozwolą zaistnieć przedsiębiorstwu w świecie konkurencji globalnej (Bednarek 2007). W praktyce globalny wymiar działalności stawia przed przedsiębiorstwami trudne i ambitne zadania, do których możemy zaliczyć:

- oferowanie klientom na całym świecie niepowtarzalnych wartości,

- zmaganie się z coraz silniejszą konkurencją o charakterze globalnym,

- przystosowanie się do wielorakich środowisk narodowych o zróżnicowanej kulturze, odmiennych systemach politycznych i gospodarczych, sposobach prowadzenia działalności oraz infrastrukturze,

- orientacja w globalnej polityce stosunków gospodarczych i handlowych,

- dostępność i poziom rozwoju infrastruktury w transporcie i telekomunikacji,

- złożoność zarządzania rozbudowaną siecią,

- czynniki geograficzne - czas, odległość, umiejscowienie rynków (Schary, Skjott-Larsen 2002). Filozofia działania firmy globalnej jest jasna: rozwijanie biznesu poprzez rozszerzanie rynków i równoczesne dążenie do osiągnięcia zgodności zakresu działań marketingowych oraz asortymentu produktów z redukcją kosztów dzięki efektowi skali w zaopatrywaniu się i produkcji (poprzez specjalizację produkcji i/lub działania montażowe) oraz w logistyce (Christopher, Peck 2005). Jedną z kluczowych decyzji firm globalnych jest wybór lokalizacji. Niezależnie od faktu, czy wybór lokalizacji odbywa się w warunkach ograniczonego wyboru, czyli w sytuacji, kiedy mamy do czynienia z kilkoma możliwymi lokalizacjami, z których jedna musi 
być wybrana, czy też wybór dokonywany jest w warunkach nieograniczonego wyboru, a zatem wówczas, gdy używamy algorytmów geometrycznych do wyznaczania optymalnej lokalizacji, przy nielimitowanych możliwościach wyboru miejsca (Waters 2001), należy pamiętać, że jest to decyzja, która ma wpływ na działanie przedsiębiorstwa przez wiele lat. Błędny wybór lokalizacji może zadecydować o porażce przedsiębiorstwa. Celem wyboru lokalizacji jest takie umiejscowienie geograficzne działalności firmy, które przyniesie najwięcej korzyści. Istnieje kilka powodów, dla których firmy poszukują nowej lokalizacji. Problemy wyboru miejsca lokalizacji są ważne zarówno dla nowo rozpoczynających działalność przedsiębiorstw, jak i dla już funkcjonujących firm. Zagadnieniami związanymi z teorią lokalizacji zajmowali się m.in. tacy ekonomiści, jak J.H. von Thünen (1826), J. Schumpeter (1912), A. Weber (1929), B. Ohlin (1967), A. Predöhl (1971), H. Giersch (1979) czy H. Siebert (2000) (Misala 2004). Lokalizowanie produkcji poza granicami kraju jest obok rozszerzenia i zdobywania nowych rynków, tworzenia joint ventures i zawierania aliansów strategicznych, działaniem będącym podstawą do ewolucji w kierunku globalizacji (Gołębiowska, Szymczak 2004).

Problematyka lokalizacyjna należy do opcji strategicznego zarządzania operacyjnego. W procesie wyborów lokalizacyjnych należy uwzględnić następujące zasady:

- tradycyjne przesłanki motywujące do inwestowania i lokalizacji rzeczowych inwestycji ustępują miejsca nowym przesłankom związanym w większym stopniu z procesem globalizacji (np. atrakcyjne punkty prowadzenia prac badawczo-rozwojowych),

- zagadnienia lokalizacyjne można z powodzeniem rozwiązywać za pomocą odpowiednio zbudowanych modeli matematycznych,

- procedury wyboru miejsc lokalizacji są procedurami wieloetapowymi (Kasiewicz 2002).

Wśród najbardziej znanych koncepcji związanych z procesami globalizacyjnymi, które mają implikacje lokalizacyjne, wymienia się teorię bezpośrednich inwestycji zagranicznych, międzynarodowy model cyklu życia produktu oraz międzynarodowy model Uppsali (tab. 1).

Tab. 1. Wybrane koncepcje związane z procesami globalizacyjnymi, które mają implikacje lokalizacyjne

\begin{tabular}{|c|c|c|}
\hline $\begin{array}{c}\text { Teoria } \\
\text { bezpośrednich } \\
\text { inwestycji } \\
\text { zagranicznych }\end{array}$ & $\begin{array}{l}\text { Inwestycje zagraniczne wynikają z cech funkcji przewag konkurencyjnych, które } \\
\text { zamierzają osiągnąc inwestorzy. Przewagi konkurencyjne mogą być związane } \\
\text { ze strukturą własności (np. technologie, patenty), lokalizacją (np. zasoby naturalne, } \\
\text { niskie koszty pracy), zdolnością równoważenia zdolności konkurencyjnych. }\end{array}$ \\
\hline $\begin{array}{c}\text { Międzynarodowy } \\
\text { model cyklu } \\
\text { życia produktu }\end{array}$ & $\begin{array}{l}\text { Czynnikami lokalizacji działalności produkcyjnych na globalnym rynku } \\
\text { są technologiczne know-how, popyt, efekty skali i koszty pracy. } \\
\text { Model wyróżnia cztery fazy: } \\
\text { 1. Wejście na rynek - dotyczy lokalizacji zakładów w krajach wysoko } \\
\text { uprzemysłowionych. }\end{array}$ \\
$\begin{array}{c}\text { 2. Faza wzrostu - rozwija się zdolności produkcyjne i eksportuje wyroby } \\
\text { na rynki trzecie. }\end{array}$ \\
$\begin{array}{c}\text { 3. Faza dojrzewania - dokonuje się realokacji potencjału produkcyjnego celem } \\
\text { redukcji kosztów (np. kosztów pracy, transportu), lokując potencjał wytwór- } \\
\text { czy w krajach nowo uprzemysłowionych lub rozwijających się. }\end{array}$ \\
$\begin{array}{c}\text { 4. Faza spadkowa - redukuje się zdolności produkcyjne, zwłaszcza w kraju } \\
\text { siedziby firmy globalnej. }\end{array}$ \\
\hline Model Uppsali & $\begin{array}{l}\text { Koncentruje się na aspektach rynkowych (np. na zakupach, przejęciach, } \\
\text { integracji, wiedzy o rynkach zagranicznych). }\end{array}$ \\
\hline
\end{tabular}

Źródło: opracowanie własne na podstawie S. Kasiewicz, Zarządzanie operacyjne w dobie globalizacji, Centrum Doradztwa i Informacji Difin sp. z o.o., Warszawa 2002, s. 192-193. 
Z analizy tych modeli wynika, że zakłady produkcyjne lokalizowane w krajach uprzemysłowionych wyróżniają się pod względem innowacyjności, natomiast zakłady produkcyjne lokalizowane w krajach rozwijających się i słabo rozwiniętych wyróżniają się czynnikiem kosztowym.

Z kolei G.S. Yip (2004) wyróżnia cztery główne strategie lokalizacji i koordynacji działalności:

- Strategia oparta na eksporcie - polega na lokowaniu możliwie największej liczby wcześniejszych ogniw łańcucha wartości w kraju macierzystym, na zewnątrz zaś tylko działalności późniejszych, takich jak sprzedaż, dystrybucja i serwis. Była to strategia typowa dla spółek japońskich i południowokoreańskich w latach 70. i 80. XX w., zanim zaczęły przenosić swoją produkcję za granicę.

- Strategia multilokalna - polega na geograficznym rozproszeniu działalności i tylko luźnym jej koordynowaniu.

- Strategia kontrolowanych bezpośrednich inwestycji zagranicznych - jest to odmiana strategii globalnej, stanowiąca często jeden z etapów odchodzenia od strategii multilokalnej. Na przykład wiele starych spółek europejskich stwierdzało w latach 80. i 90. XX w., że ich działalność jest nadmiernie rozproszona, co nie odpowiada warunkom nowej gospodarki w globalizującym się świecie. Pierwszą reakcją na ten fakt było nasilenie koordynacji, a potem następowało ograniczenie liczby miejsc prowadzenia działalności.

- Czysta strategia globalna - polega na koncentrowaniu działalności, ale - w odróżnieniu od strategii opartej na eksporcie - niecała działalność spółki jest lokowana w jej kraju macierzystym, lecz w kilku różnych krajach, przy czym w każdym z nich jest umiejscowiony inny jej rodzaj.

Ryc. 1. Decyzje dotyczące lokalizacji i koordynacji działalności

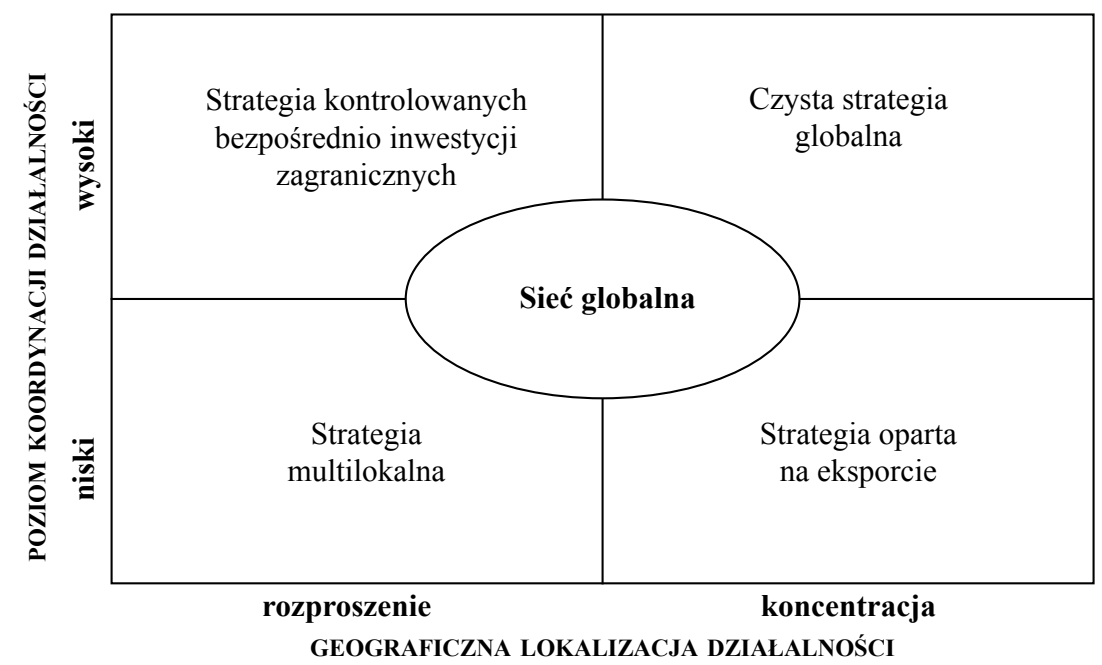

Źródło: G.S. Yip, Strategia globalna, PWN, Warszawa 2004, s. 209.

Od początku lat 20. do końca lat 60 . XX w. system masowej produkcji skłaniał korporacje transnarodowe do bezpośredniego zaangażowania się za granicą na podstawie motywów rynkowych i zasobowych, a najbardziej odpowiednim sposobem organizowania działalności 
produkcyjno-handlowej był model wielonarodowy. Czynniki techniczno-organizacyjne implikowały lokalizację produkcji międzynarodowej na dużych i chłonnych rynkach zaopatrzenia i zbytu w tym większym zakresie, im bardziej były chronione barierami handlowymi, posiadały obfite i tanie zasoby, położone były niezbyt daleko i miały podstawową infrastrukturę (porty, drogi, szlaki kolejowe). W latach 50. i 60. silnie ekspansywne amerykańskie korporacje transnarodowe preferowały lokowanie działalności produkcyjno-handlowej na terenie Europy Zachodniej (przetwórstwo przemysłowe) oraz Kanady i Ameryki Łacińskiej (w przetwórstwie i wydobyciu). W miarę dojrzewania wiodących gałęzi przemysłu (np. samochodowego, elektronicznego) i narastania motywów efektywnościowych w masowej produkcji, w latach 70 . organizacja działalności korporacji transnarodowych na zagranicznych rynkach ewoluowała w kierunku modelu międzynarodowego. Konsekwencją tych procesów był wzrost znaczenia zagranicznych inwestycji bezpośrednich oraz generowanej przez nie produkcji międzynarodowej w krajach o niskich cenach zasobów wytwórczych (zwłaszcza nisko kwalifikowanej siły roboczej), posiadających odpowiednią bazę przemysłową i infrastrukturę (łączność, lotniska, porty dla przeładunków kontenerowych) oraz prowadzących względnie liberalną politykę importową lub promującą eksport i napływ zagranicznych inwestycji bezpośrednich. Nadal istotne znaczenie lokalizacyjne miały duże rynki zbytu masowej produkcji, gdzie korzyści dużej skali działania można było realizować nie tylko w wytwarzaniu, lecz również w dystrybucji, reklamie i usługach posprzedażnych (Zaorska 1998).

Omawiając niższe koszty międzynarodowej produkcji, należy stwierdzić, że od końca lat 60. wiele korporacji transnarodowych z różnych krajów preferuje walory lokalizacyjne krajów nowo uprzemysłowionych, przede wszystkim azjatyckich. Natomiast względy rynkowe, technologiczne i konkurencyjne skłaniały amerykańskie i japońskie korporacje transnarodowe do lokowania zagranicznych inwestycji bezpośrednich w nowoczesnych branżach, głównie na terenie Europy Zachodniej, a korporacje zachodnioeuropejskie i japońskie do bezpośredniego angażowania się na rynku w USA. W latach 80. zaczęto upowszechniać stosowanie transnarodowego modelu organizacji działalności korporacji transnarodowych. Lokalizacja działalności korporacji transnarodowych stała się pochodną dążenia organizacji do osiągania globalnej efektywności, plasowania się na najbardziej atrakcyjnych rynkach, pozyskiwania zaawansowanych zasobów wytwórczych oraz realizowania taktyki lokalizacyjnej, która umacniała obecność korporacji na strategicznie ważnych odcinkach (Zaorska 1998). Rzadko jednak zdarza się, aby jakieś przedsiębiorstwo mogło stwierdzić, że jego obecny model lokalizacji jest optymalny. $\mathrm{Z}$ powodu zmieniających się warunków globalizacji oraz niedostatku myślenia strategicznego w przeszłości, wiele, a być może nawet większość, przedsiębiorstw odkrywa, że charakter sieci ich działalności nie odpowiada potencjałowi globalizacyjnemu sektora, w którym operują (Yip 2004).

Dążenie do niskich kosztów robocizny stwarza pewien dylemat, ponieważ może oznaczać wybór miejsca, z którego czas transportu na rynki jest długi. Długi czas transportu z reguły generuje wyższe koszty składowania zapasów na rynku. Ponadto może on również wywoływać nieodpowiednie reakcje na zmiany popytu. Dlatego też wiele firm decyduje się na wybór lokalizacji o wyższych kosztach, lecz położonej bliżej rynku (Schary, Skjott-Larsen 2002). J. Ishikawy i Y. Komariya dowiedli, że o lokalizacji przedsiębiorstwa przesądza nie różnica w kosztach produkcji pomiędzy różnymi firmami, ale różnica w kosztach pomiędzy krajową a zagraniczną produkcją tego samego przedsiębiorstwa (Ishikawy, Komariya 2008).

G.S. Yip w swej Strategii globalnej oddziela tradycyjne czynniki lokalizacji od przesłanek lokalizacyjnych firm globalnych. 
Tab. 2. Czynniki lokalizacji

\begin{tabular}{|l|l|}
\hline \multicolumn{1}{|c|}{ Tradycyjne czynniki lokalizacji } & \multicolumn{1}{c|}{ Przesłanki lokalizacyjne firm globalnych } \\
\hline - lokalizowanie firm tam, gdzie koszty wytwarza- & • atrakcyjność z punktu widzenia prowadzenia \\
nia, tzn. surowców, materiałów i innych & prac badawczo-rozwojowych (źródło \\
czynników produkcji są niższe przy danym & innowacji, wysoko wykwalifikowana kadra) \\
wolumenie (przewaga komparatywna) & i oczekiwań wymagających klientów \\
- niższe podatki & - atrakcyjny klimat inwestycyjny (np. stabil- \\
- kwestie wzrostu produktywności i osiągania & ność polityczna, podatki, prawo) oraz \\
wysokiej jakości & czynniki i warunki sprzyjające budowaniu \\
- dogodny transport & konkurencyjnej i strategicznej przewagi \\
- jakość siły roboczej & (np. bliskość głównych rynków, efekt kraju \\
- koszt kapitału & pochodzenia, obecność konkurentów) \\
- infrastruktura gospodarcza & polityka kursów wymiany walut (związek \\
- poziom ryzyka politycznego & z produktywnością) \\
\hline
\end{tabular}

Źródło: G.S. Yip, Strategia globalna, PWN, Warszawa 1996, s. 134-140.

W obecnych warunkach technicznych i ekonomicznych wzrastają możliwości wyboru lokalizacji dla globalnie zorientowanej działalności jednostek organizacyjnych korporacji transnarodowych. Następuje zmiana podejścia korporacji transnarodowych do oceny walorów lokalizacyjnych, wśród których relatywnie mniej cenione stają się walory statyczne i ilościowe, a bardziej poszukiwane - walory dynamiczne i jakościowe. Przede wszystkim chodzi o tworzone, zaawansowane zasoby i zdolności, o nowo powstające rynki - integrowane lub wschodzące - oraz o formujące się skupiska branżowo wyspecjalizowanych przedsiębiorstw. Kierunki poszukiwań lokalizacyjnych przez korporacje transnarodowe - ze względu na charakter potrzebnych im walorów - skupiają się głównie na obszarze Triady (tworzą ją trzy obszary: Europa Zachodnia, Ameryka Północna i część Azji Południowo-Wschodniej). Chodzi nie tylko o obecnie istniejący, wysoki poziom rozwoju i zaawansowania zasobów, lecz także o długofalową zdolność polityki państwa do podnoszenia jakości zasobów oraz usprawniania pracy rynku. W praktyce stosunkowo najlepiej spełniają te wymagania kraje rozwinięte i nowo uprzemysłowione (Zaorska 1998). Warto również wspomnieć, iż lokalizacja wielu usług stała się w znacznej mierze niezależna od lokalizacji ich odbiorców. Wcześniej usługi musiały być świadczone w tym samym miejscu i czasie, w którym były konsumowane. Większości z nich nie można było składować i przesyłać na odległość. Obecnie eksportować bądź importować można właściwie każdy rodzaj usług niewymagający osobistego kontaktu z klientem (Gierańczyk 2008).

Na początku obecnego wieku prawie 90\% korporacji transnarodowych miało swoje siedziby macierzyste w krajach Triady. Do największych korporacji należały: General Electric, Exxon Mobil Corporation, Royal Dutch Shell Group, General Motors oraz Ford Motor Company. Filie korporacji transnarodowych zlokalizowane były głównie w krajach wysoko rozwiniętych; połowa z nich działała w Europie, a 10\% w Ameryce Północnej. Na kraje rozwijające się przypadało około 25\% filii i oddziałów. Jednocześnie kraje rozwijające się, takie jak Hongkong, Korea Południowa, Meksyk i Wenezuela, stworzyły własne korporacje transnarodowe, zwłaszcza w przemyśle petrochemicznym i elektronicznym (Radzymińska 2001). Według portalu http://money.cnn.com listę 500 największych firm światowych w roku 2010 według kryterium osiąganego dochodu otwierają Wal-Mart Stores, Royal Dutch Shell oraz Exxon Mobil. Niestety, wśród 500 największych firm tylko jedna pochodzi z Polski. Jest to sklasyfikowana na 398 miejscu Grupa PKN Orlen. 
Proces wyboru lokalizacji składa się z kilku etapów. Harrison oraz van Hoek w Zarządzaniu logistyka proponują następujące etapy procesu decyzyjnego dotyczącego wyboru lokalizacji:

Ryc. 2. Etapy procesu wyboru lokalizacji

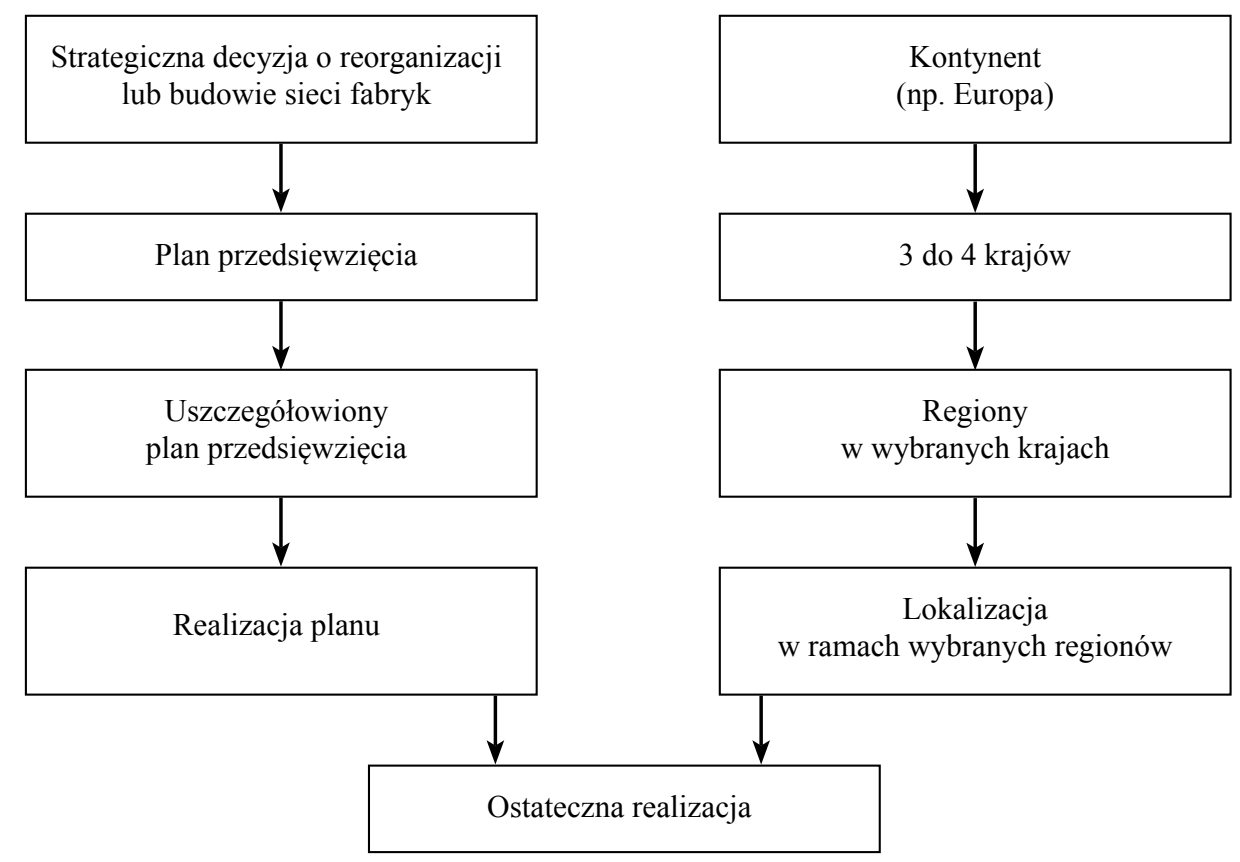

Źródło: A. Harrison, R. van Hoek, Zarządzanie logistyką, Polskie Wydawnictwo Ekonomiczne, Warszawa 2010, s. 172.

Z kolei S. Kasiewicz w książce Zarządzanie operacyjne $w$ dobie globalizacji, opierając się na pracach A.D. MacCormacka, L.J. Newmana III oraz D.B. Rosenfielda, proponuje bardziej szczegółowy, czteroetapowy model wyboru lokalizacji dla firm globalnych.

Tab. 3. Etapy wyboru lokalizacji dla firm globalnych

\begin{tabular}{|c|c|}
\hline $\begin{array}{l}\text { 1. Ustalenie krytycznych czynników } \\
\text { sukcesu, stopnia koniecznej globalnej } \\
\text { orientacji i wymaganego wsparcia } \\
\text { menedżerów }\end{array}$ & $\begin{array}{l}\text { - Ustalenie, w jakim elemencie firma globalna } \\
\text { konkuruje (koszt, jakość, innowacyjność czy } \\
\text { elastyczność) i pokazanie związku rodzaju } \\
\text { konkurencji z wyborem miejsca lokalizacji. Firma, } \\
\text { która zamierza uzyskać przywództwo kosztowe, } \\
\text { będzie poszukiwać lokalizacji redukującej koszty } \\
\text { transportu, pracy i zapasów. Natomiast firma } \\
\text { globalna dążąca do przywództwa innowacyjnego } \\
\text { będzie preferować lokalizacje zapewniające } \\
\text { bliskość klientów i wykształcone zasoby ludzkie. }\end{array}$ \\
\hline
\end{tabular}




\begin{tabular}{|c|c|}
\hline & $\begin{array}{l}\text { - Prognozowanie ewolucji branży i wymagań } \\
\text { rynkowych wynikających z globalizacji. Branża } \\
\text { może zmierzać do konsolidacji skali, zakresu lub } \\
\text { fragmentaryzacji nisz rynkowych. Menedżerowie } \\
\text { muszą ustalić, jakie czynniki i w jakim stopniu } \\
\text { będą determinować rozwój branży oraz jakie } \\
\text { wynikają stąd przesłanki dla lokalizacji potencjału } \\
\text { produkcyjnego. } \\
\text { - Ocena wewnętrznych ograniczeń firmy w realizacji } \\
\text { optymalnej strategii lokalizacyjnej. Jeśli firma nie } \\
\text { jest w stanie sfinansować programu inwestycyjne- } \\
\text { go, to powinna dążyć do zawarcia aliansu } \\
\text { strategicznego z inną firmą. } \\
\text { Synteza wpływu rozważanych czynników na treść } \\
\text { strategii operacyjnej firmy globalnej. }\end{array}$ \\
\hline $\begin{array}{l}\text { 2. Ocena opracowanych opcji konfiguracji } \\
\text { regionalnych zdolności produkcyjnych } \\
\text { uwzględniających dostęp do rynku, } \\
\text { ryzyko zarządzania, charakterystyki } \\
\text { popytu klienta i wpływ technologii } \\
\text { produkcji na wielkość zakładów }\end{array}$ & $\begin{array}{l}\text { Ocena politycznych i rynkowych barier wejścia. } \\
\text { Najlepiej jest preferować lokalizacje w strefach } \\
\text { bloków handlu (np. NAFTA, UE). } \\
\text { - Ocena regionalnego stopnia ryzyka prowadzenia } \\
\text { działalności (lokalizacja potencjału produkcyjnego } \\
\text { w rejonie wysokiego i stabilnego wzrostu jest } \\
\text { mniej ryzykowna, niż lokowanie w rejonach } \\
\text { niskich dochodów, wysokiego bezrobocia i strefach } \\
\text { występowania potencjalnych napięć społecznych). } \\
\text { Określenie wpływu technologii produkcji na } \\
\text { wielkość zakładu (liczba potencjalnych lokalizacji, } \\
\text { wielkość produkcji, zmiany w czasie zdolności } \\
\text { produkcyjnych). }\end{array}$ \\
\hline $\begin{array}{l}\text { 3. Określenie zbioru potencjalnych miejsc } \\
\text { lokalizacji bazuje zasadniczo na } \\
\text { infrastrukturze, która ma wspierać } \\
\text { prowadzoną działalność i strategię } \\
\text { produkcyjną firmy }\end{array}$ & $\begin{array}{l}\text { - Ocena metodologii produkcji dla każdej lokaliza- } \\
\text { cji. W ocenie określa się wielkość zatrudnienia, } \\
\text { niezbędną bazę dostawców i infrastrukturę } \\
\text { transportowo-komunikacyjną. Ocena infrastruktury } \\
\text { winna objąć elementy twarde i miękkie (poziom } \\
\text { wykształcenia pracowników, certyfikaty dostaw- } \\
\text { ców itp.). } \\
\text { - Badanie poziomu rozwoju infrastruktury rozpatry- } \\
\text { wanych wariantów lokalizacji i ocena, która } \\
\text { lokalizacja zapewnia infrastrukturę zgodną } \\
\text { z przyjętą globalną strategią firmy. }\end{array}$ \\
\hline $\begin{array}{l}\text { 4. Przeprowadzenie rankingu rozważanych } \\
\text { lokalizacji według najbardziej efektyw- } \\
\text { nych rozwiązań pod względem kosztu } \\
\text { w oparciu o wyniki analizy ilościowej, } \\
\text { a następnie ustalenie sposobu działania }\end{array}$ & - Wybór lokalizacji. \\
\hline
\end{tabular}

Źródło: opracowanie własne na podstawie S. Kasiewicz, Zarządzanie operacyjne w dobie globalizacji, Centrum Doradztwa i Informacji Difin sp. z o.o., Warszawa 2002, s. 189-191. 
Interesującym wydaje się być również fakt, iż podczas gdy trend do globalizacji gałęzi przemysłu i przedsiębiorstw wydaje się zmniejszać wagę i odrębność subregionów, to tendencja do lokalizacji określonych gałęzi przemysłu i działalności ekonomicznej wydaje się działać w przeciwnym kierunku. Jedna z prób wyjaśnienia tego paradoksu oparta została na teorii grona (Enright, Ffowcs-Williams 2000). Warto w tym miejscu wspomnieć, że w rozwoju i funkcjonowaniu gron istotną rolę odgrywają takie czynniki, jak:

- Dostępność wyspecjalizowanych nakładów i pracowników. Zaopatrywanie się firm na miejscu, czyli wewnątrz grona, minimalizuje konieczność przechowywania zapasów, eliminuje koszty importu, skraca czas oczekiwania, ułatwia komunikację, zmniejsza koszty dostosowania się do szczególnych potrzeb i ułatwia wspólne świadczenie usług pomocniczych, takich jak instalowanie urządzeń, usuwanie wad czy szkolenie pracowników.

- Dostęp do informacji. Firmy i miejscowe instytucje wchodzące w skład grona gromadzą wiele specjalistycznych informacji rynkowych, technicznych oraz z zakresu innych dziedzin. Wewnątrz grona można uzyskać do nich dostęp skuteczniej albo taniej, co umożliwia podwyższanie efektywności.

- Komplementarność. Grono sprzyja zwiększaniu efektywności nie tylko poprzez pozyskiwanie i kojarzenie nakładów, ale także przez wzajemne uzupełnianie się czynności wykonywanych przez uczestników grona, czego wyrazem jest komplementarność produktów. Oznacza to, że poszczególne części grona są zależne od siebie i mogą się wzajemnie wspierać.

- Dostęp do instytucji i dóbr publicznych. Grona przekształcają w dobra publiczne wiele nakładów, które w innym przypadku byłyby kosztowne (np. możliwość zatrudnienia pracowników przeszkolonych na miejscowych kursach eliminuje lub obniża koszty szkolenia wewnętrznego).

- Zachęty i pomiar efektywności. Grona stwarzają okazję do osiągania większej efektywności działania firmy, głównie ze względu na rywalizację z konkurentami wewnątrz grona, którzy działają w podobnych warunkach i z którymi łatwo jest się porównywać. Ułatwiają one także pomiar efektywności czynności wykonywanych wewnątrz firmy, gdyż często inne miejscowe przedsiębiorstwa spełniają podobne funkcje. Menedżerowie uzyskują zatem większe możliwości porównywania ponoszonych kosztów transakcji zawieranych na zewnątrz i obniżania kosztów monitoringu pracowników przez porównywanie na miejscu ich wydajności z innymi jednostkami (Berliński, Penc-Pietrzak 2004). Opierając się na teorii grona, niektóre przedsiębiorstwa chętnie lokują swoją działalność w miejscach, gdzie mają łatwy dostęp do specjalistów w danej dziedzinie. Za przykład mogą posłużyć ośrodki innowacji informatycznych, takie jak Krzemowa Dolina w Kalifornii czy Krzemowe Moczary wokół Cambridge w Wielkiej Brytanii. Do ich powstania przyczyniły się firmy, które umieszczały tam swoje siedziby, gdyż chciały korzystać z wyników badań prowadzonych na pobliskich uniwersytetach. Z drugiej strony, im więcej firm w takim ośrodku, tym większy wpływ mają one na kierunki badań i tym większe korzyści mogą w ich rezultacie osiągnąć. Efekt ten ulega spotęgowaniu, gdy firmy koncentrują w jednym miejscu całą swoją działalność badawczo-rozwojową. Z jednej strony może to oznaczać odcięcie się od innych źródeł utalentowanych pracowników, $\mathrm{z}$ drugiej strony pomaga w przyciągnięciu młodych, zdolnych ludzi, którzy w przyszłości będą nadawać ton w danej branży i sprzyja wytwarzaniu synergii między zespołami badawczymi (Harrison, Hoek 2010).

Jedną z polskich firm, która stosuje strategię globalnego rozwoju, tworząc filie za granicą lub przejmując miejscowe firmy w celu ulokowania współzależnych przedsiębiorstw w różnych krajach i regionach, jest Grupa Selena z województwa dolnośląskiego. Grupa Selena to holding 
spółek zajmujących się produkcją i dystrybucją chemii budowlanej, prowadzący działalność na całym świecie i oparty na polskim kapitale. Powstał on w roku 1992 jako jedna z pierwszych firm w Polsce oferujących nowoczesne produkty chemii budowlanej: poliuretanowe piany montażowe i uszczelniacze silikonowe. W ciągu zaledwie kilku lat firma zdobyła znaczącą pozycję na krajowym rynku pian i silikonów. W celu dalszego rozwijania firmy w oparciu o innowacje i wysoką jakość produktów, zdecydowano się na uruchomienie własnej produkcji. Kolejno powstały zakłady produkcyjne pian, uszczelniaczy oraz klejów. Pod koniec lat 90. Grupa Selena poszukiwała dalszych możliwości rozwoju w branży, a te oferował eksport i ekspansja międzynarodowa. Stworzono zagraniczne spółki handlowe, a kolejnym krokiem w rozwoju firmy było rozpoczęcie działalności produkcyjnej za granicą: w Korei Południowej, Brazylii, USA, Chinach i we Włoszech. W skład Grupy Selena wchodzi obecnie 30 spółek krajowych i zagranicznych, w tym 12 zakładów produkcyjnych (sześć zakładów w Polsce, po jednym w Hiszpanii, Brazylii, Korei Południowej, Chinach, USA oraz Turcji). Działalność Grupy Selena obejmuje wszystkie etapy tworzenia produktów: począwszy od zaawansowanych badań, poprzez produkcję, dystrybucję, marketing, aż po sprzedaż na całym świecie. Obecnie holding jest czwartym pod względem wielkości producentem piany poliuretanowej na świecie, skutecznie konkurującym na światowych rynkach chemii budowlanej z globalnymi koncernami o wieloletniej tradycji. Grupa Selena systematycznie rozbudowuje własne zaplecze produkcyjne, zarówno poprzez zwiększanie zdolności produkcyjnych zakładów w Polsce, jak i stopniową intensyfikację działalności produkcyjnej za granicą. O lokalizacji nowej zagranicznej inwestycji decydują w wypadku przejęć podmiotów zagranicznych korzyści wynikające z rozszerzenia skali działalności oraz poszerzenia portfela o zagraniczne marki. Natomiast w wypadku wspólnych przedsięwzięć Grupy Selena z zagranicznymi firmami, wybór lokalizacji determinują korzyści wynikające z włączenia produktów Seleny do sieci dystrybucyjnych partnera oraz możliwość dokapitalizowania i wykorzystania terenu produkcyjnego podmiotu zagranicznego do wytwarzania podstawowych produktów (http://www2.selena.pl/cms/index.php).

W niniejszej pracy podjęłam próbę pokazania, jak od strony teoretycznej rozpatrywany jest bardzo praktyczny problem wyboru lokalizacji produkcji przez podmioty gospodarcze. Podsumowaniem pracy niech będą zaproponowane przez G.S. Yipa wskazówki do lokalizowania globalnej działalności:

- Przy lokalizowaniu działalności menedżerowie powinni odblokować swoje myślenie przez startowanie od podstawy zero i przyjmowanie założenia, że ich przedsiębiorstwo dotychczas nie prowadzi nigdzie na świecie żadnej działalności. Następnie powinni zadać sobie pytanie, jaki powinien być idealny model lokalizacji działalności i dopiero potem powrócić do uwzględniania faktu, gdzie już obecnie jest zlokalizowana działalność firmy i ile kosztowałoby jej przemieszczenie.

- Różnych rodzajów działalności dotyczą odmienne potrzeby w zakresie globalnej koncentracji, lokalnego rozproszenia lub obydwu tych rozwiązań łącznie.

- Idealny model lokalizacji działalności zmienia się wraz ze zmianami zewnętrznymi i wewnętrznymi przedsiębiorstwa.

- Najlepszy model lokalizacji zazwyczaj pozostawia pewne powielanie działalności w celu zachowania elastyczności i zabezpieczenia się przed nieciągłością.

- Koordynowanie geograficzne rozproszonych działalności może w niektórych przypadkach służyć jako substytut globalnej koncentracji.

- Przy lokalizowaniu działalności ze względu na maksymalizację przewagi konkurencyjnej menedżerowie powinni brać pod uwagę przewagę zarówno strategiczną, jak i komparatywną (na bazie krajowej). 
- Niektóre rodzaje działalności, zwłaszcza prace badawczo-rozwojowe, powinny być umiejscowione w krajach o globalnym znaczeniu strategicznym (Yip 2004).

$\mathrm{W}$ praktyce niezwykle istotnym jest, aby menedżerowie stający przed wyzwaniem dokonania wyboru lokalizacji dla działalności ich firmy, nie polegali tylko i wyłącznie na swojej intuicji, ale byli świadomi istnienia aparatu teoretycznego opisującego ten skomplikowany proces.

\section{Literatura}

1. Bednarek M., 2007, Doskonalenie systemów zarzązania. Nowa droga do przedsiębiorstwa lean, Centrum Doradztwa i Informacji Difin Sp. z o.o., Warszawa.

2. Berliński L., Penc-Pietrzak I., 2004, Inżynieria projektowania strategii przedsiębiorstwa. Konstrukcja i technologia, Centrum Doradztwa i Informacji Difin Sp. z o.o., Warszawa.

3. Budnikowski A., 2000, Zagrożenia związane z globalizacją i możliwości ich pokonywania, Kolegium Gospodarki Światowej SGH, „Zeszyty Naukowe”, nr 9, Warszawa.

4. Christopher M., Peck H., 2005, Logistyka marketingowa, Polskie Wydawnictwo Ekonomiczne, Warszawa.

5. De Wit B., Meyer R., 2007, Synteza strategii, PWE, Warszawa.

6. Enright M.J., Ffowcs-Williams I., 2000, Local partnership, clusters and some globalization, OECD, Italy.

7. Flejterski S., Wahl P. T., 2003, Ekonomia globalna, Centrum Doradztwa i Informacji Difin Sp. z o.o., Warszawa.

8. Gierańczyk W., 2008, Problematyka definiowania zmian $w$ tendencjach lokalizacyjnych przedsiębiorstw przemysłowych $w$ dobie globalizacji, Problematyka badawcza geografii przemysłu, Z. Zioło, T. Rachwał (red.), „Prace Komisji Geografii Przemysłu PTG, nr 11, Komisja Geografii Przemysłu PTG i Zakład Przedsiębiorczości i Gospodarki Przestrzennej Instytutu Geografii Akademii Pedagogicznej w Krakowie, Warszawa-Kraków.

9. Gołębiowska E., Szymczak M., 2004, Logistyka międzynarodowa, PWE, Warszawa.

10. Gurría A., 2006, Managing globalization and the role of the OECD, http://www.oecd.org/document/ 52/0,3343,en_2649_37447_37478942_1_1_1_1,00.html.

11. Harrison A., Van Hoek R., 2010, Zarządzanie logistyka, PWE, Warszawa.

12. Hetmańczyk A., Noga B., 2008, Nowa faza globalizacji a zmiany inflacji [w:] Globalizacja a konkurencyjność w gospodarce światowej, M. Noga, M.K. Stawicka (red.), CeDeWu Sp. z o.o., Warszawa.

13. http://money.cnn.com/magazines/fortune/global500/2010/full_list/index.html.

14. http://www2.selena.pl/cms/index.php.

15. Ishikawy J., Komariya Y., 2008, Stay or leave? Choice of plant location with cost heterogeneity, http:// www.econ.hit-u.ac.jp/ jota/downloadfiles/IshiKomJERfinal.pdf.

16. Jeannet J.P., 2000, Managing with a Global Mindset, Biddles Ltd., Guildford \& King's Lynn, Great Britain.

17. Kaliński J., 2004, Globalizacja w perspektywie historycznej [w:] Globalizacja od A do Z, A. Czarny (red.), NBP, Warszawa.

18. Kasiewicz S., 2002, Zarządzanie operacyjne $w$ dobie globalizacji, Centrum Doradztwa i Informacji Difin Sp. z o.o., Warszawa.

19. Kołodko G.W., 2008, Wędrujący świat, Wydawnictwo Prószyński i Spółka, Warszawa.

20. Liberska A. (red.), 2002, Globalizacja, mechanizmy $i$ wyzwania, PWE, Warszawa. 
21. Matysek-Jędrych A., 2008, Współczesne przeobrażenia systemu finansowego i ich konsekwencje, „Bank i Kredyt”, nr 1, Warszawa.

22. Misala J., 2004, Lokalizacja działalności gospodarczej w warunkach globalizacji (ujęcie teoretyczne) [w:] Globalizacja od A do Z, A. Czarny (red.), NBP, Warszawa.

23. Misiak W., 2007, Globalizacja więcej niż podręcznik, Centrum Doradztwa i Informacji Difin Sp. z o.o., Warszawa.

24. Piasecki R., 2003, Rozwój gospodarczy a globalizacja, PWE, Warszawa.

25. Potocki A., 2004, Globalizacja a zachowania organizacyjne menedżerów, „Zeszyty Naukowe”, nr 647, Akademia Ekonomiczna, Kraków.

26. Potocki A. (red.), 2009, Instrumenty $i$ obszary przeobrażeń i zmian organizacyjnych $w$ warunkach globalizacji, Difin S.A., Warszawa.

27. Radzymińska T., 2001, Największe korporacje transnarodowe, „Nowe Życie Gospodarcze”, nr 20, Warszawa.

28. Sala S., 2006, Bezpośrednie inwestycje zagraniczne, a procesy globalizacji, „Prace Komisji Geografii Przemysłu PTG”, nr 8, Warszawa, Kraków.

29. Schary P.B., Skjott-Larsen T., 2002, Zarządzanie globalnym łańcuchem podaży, PWN, Warszawa.

30. Stabryła A., 2007, Formuła globalizacji w planowaniu strategicznym [w:] Potencjat restrukturyzacji $w$ warunkach globalizacji $i$ nowej gospodarki, R. Borowiecki, A. Jaki (red.), Wydawnictwo UEK, Kraków.

31. Yip G.S., 1996, Strategia globalna. PWN, Warszawa.

32. Yip G.S., 2004, Strategia globalna, PWN, Warszawa.

33. Zaorska A., 1998, Ku globalizacji? Przemiany $w$ korporacjach transnarodowych $i$ gospodarce światowej, Warszawa.

\section{Location of Companies as a Function of Globalization Processes}

Choosing a proper location is a critical issue for each global company. This work is an attempt to look from the theoretical perspective at a very practical problem, namely, how to determine the best location for making business. The dilemma is presented in the context of the globalization processes. These processes give a framework for companies operating globally and pose both threat and an opportunity for their development. The case study was based on the analysis of the Selena Group, which is undoubtedly one of the pioneers among Polish companies aspiring to gain status of the global enterprise. The first part of this work includes the definition of the term of globalization both in a broad and a narrow scope as well as short information on the origins of the globalization processes. The second part comprises of the presentation of several globalization concepts which refer to the problem of choosing a location. There are also discussed factors influencing location as well as the stages of the process of selecting a location. 